Geologische Rundschau 81/2 | 383-389 | Stuttgart 1992

\title{
Abrasion in pyroclastic flows
}

\author{
By A. FreundT and H.-U. SCHMINCKE, Kiel*)
}

With 7 figures and 1 table

\section{Zusammenfassung}

Die relative Größe von Glassäumen um Kristalle in der Matrix-Asche kann als semi-quantitatives Maß für den Abrieb von Aschepartikeln in pyroklastischen Strömen benutzt werden. Median-Werte des Abriebs-Index (= Fläche Kristall $_{\text {/ Fläche }}$ Glassaum $)$ betragen 8,4 bis 18,5 in pyroklastischen Fließeinheiten am Laacher See. Abriebs-Indices stratigraphisch assoziierter Bims-Fallablagerungen liegen bei nur 4 bis 6,3; dies belegt einen höheren Abrieb von Aschepartikeln in den pyroklastischen Strömen. Alle Pyroklasten erfahren gemeinsam starken $\mathrm{Ab}$ rieb im Schlot, aber Partikel in pyroklastischen Strömen durchlaufen eine zweite Phase starken Abriebs während des hochenergetischen Transports im schlotnahen Bereich. Bei niedriger-energetischem Fließen mit wachsender Bingham-Festigkeit weiter talabwärts wird der Partikelabrieb schwächer. Hohe Gehalte an feiner Asche in distalen Fließeinheiten sind also eher auf schwächer werdende Elutriierung als auf stärkeren Abrieb zurückzuführen.

\section{Abstract}

The relative size of glass rims coating crystals in the matrix ash provides a semi-quantitative measure of abrasion of ash grains in pyroclastic flows. Median abrasion indices $\left(=\right.$ area $_{\text {crystal }} /$ area glass rim $)$ are 8.4 to 18.5 in Laacher See pyroclastic flow units but only 4 to 6.3 in assocciated fallout, showing stronger abrasion of ash particles in the pyroclastic flows. All pyroclasts undergo strong attrition in the vent but clasts in pyroclastic flows undergo a second major phase of abrasion during high-energy near-vent flow. Abrasion of ash particles is weaker during lower-energy higher-strength motion further downstream, suggesting that high contents of fine ash in distal deposits are due to diminishing elutriation rather than high rate of attrition.

\section{Résumé}

La dimension relative des enduits vitreux qui enrobent les cristaux dans les dépôts de cendres volcaniques peut être utilisée comme mesure semiquantitative de l'abrasion des particules dans les courants pyroclastiques. Au Laacher See les indices d'abrasion (surface du cristal/surface de l'enduit vitreux) sont de 8,4 à 18,5 dans les coulées pyroclastiques et seulement de 4 à 6,3 dans les sédiments formés par retombée, qui leur sont interstratifiés; les particules de cendre ont donc subi une abrasion plus forte dans les coulées. Tous les pyroclastes subissent une forte abrasion dans le cratère; mais dans les coulées pyroclastiques, ils subissent une deuxième action d'abrasion au cours de leur transport en milieu de haute énergie, à proximité du cratère. Dans les conditions de plus basse énergie qui règnent plus en aval, l'abrasion est moins forte; on en déduit que la forte teneur en fines dans les dépôts distaux résulte d'une diminution de l'élutriation plutôt que d'une forte action d'abrasion.

\section{Краткое содержание}

Относительную величину стеклоподобньх корочек на поверхности кристалликов в вулканическом пепле матрицы можно применять,

*) Authors' address: A. FreUndT and H.-U. SchMinCKE, GEOMAR, Wischhofstr. 1-3, D-2300 Kiel 14, FRG.

Manuscript received: 21. 8. 91; accepted: 25. 11. 91 
как полуколичественную оценку истирания частичек пепла в пирокластических потоках. Средние значения индекса истирания (Поверхность кристалJ//пверхность $\left._{\text {корочка }}\right)$ колеблется от 8,4 до 18,5 в единицах пирокластических потоков озера Лаах. Индексы истирания в стратиграфически связанных отложениях пемзы составляют кластических потоках. Все пирокласты претерпевают общее сильное истирание уже в жерле, но частички претерпевают еще и вторую фазу их сильного истирания во время переноса потоками высокой энергии в регионы вокруг жерла. Это явление ослабляется в потоках низкой энергии с возрастающим затвердеванием, идущих далее по склону. Явления интенсивного истирания материала в мелкозернистом пепле отдельных участков потока скорее всего следует отнести за счет ослабления отмучивания (элюстриации), а не истирания.

\section{Introduction}

Flowing particulate systems like pyroclastic flows should be inherently grain-abrasive. Here we study effects of grain abrasion in pyroclastic flow deposits at Laacher See Volcano, emphasizing the size of glass rims adhering to crystals as a potential measure for abrasion.

Non-welded pyroclastic flow deposits make up $0.6 \mathrm{~km}^{3}$ of the $16 \mathrm{~km}^{3}$ total tephra erupted by the 11,000 a old phonolithic Laacher See volcano in the East Eifel Volcanic Field (Germany). They were emplaced as three eruptive units (T1, T2, T3; FREUNDT \& SCHMINCKE, 1985a) intercalated with Plinian fallout (T1, T2) and Vulcanian fallout and surge deposits (T3). Figure 1 shows the distribution of the major unit, T1, whose valley-filling (FREUNDT \& SCHMINCKE, 1985b, 1986) and overbank facies (SCHUMACHER \& SCHMINCKE, 1990) have been studied in some detail. T1 extends more than $10 \mathrm{~km}$ from the vent, reaches up to $60 \mathrm{~m}$ total thickness in deep valleys, represents $0.3 \mathrm{~km}^{3}$ tephra, and consists of 19 flow units containing lapilli pipes, lithic-rich layers and pods, local lithic breccias and rare lithicrich ground layers (FREUNDT \& SCHMINCKE, 1985b). The depositing flows are inferred to have moved as Bingham fluids over most of their transport distance, with strength increasing downstream while fluidization efficiency decreased (FREUNDT \& SCHMINCKE, 1986).

Individual flow units of $\mathrm{T} 1$ were correlated in the deep northern canyons between about 3 to $6 \mathrm{~km}$ from the rim of Laacher See crater basin, i.e. about 4.5 to

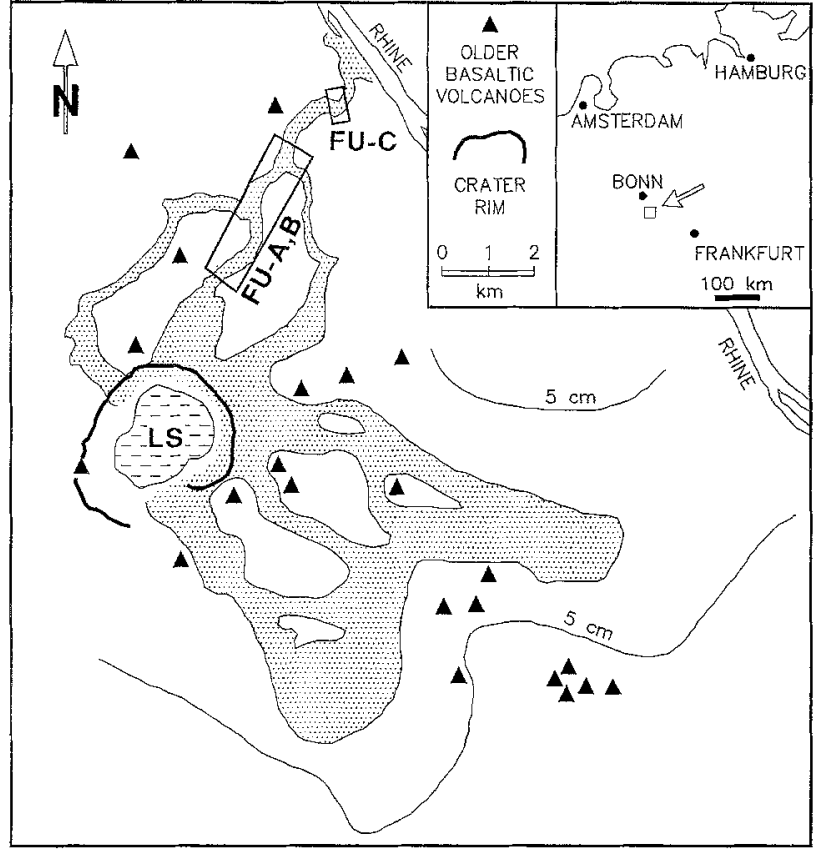

Fig. 1. Distribution of T1 pyroclastic flow deposits around Laacher See (LS) volcano. Dotted area is valley-filling ignimbrite within its $4 \mathrm{~m}$ - isopach, thin lines indicate the $5 \mathrm{~cm}-$ isopach of the overbank facies. Boxes in the north show the sampling area for flow units $\mathrm{A}, \mathrm{B}$ and $\mathrm{C}$. The eruptive vent moved from the southern shore of the lake into its NE sector during the MLST-B phase generating the T1 pyroclastic flows; therefore, distances are here measured from the crater rim but adding approximately $1.5 \mathrm{~km}$ gives distances from the vent.

$7.5 \mathrm{~km}$ from the vent (Fig. 1). Data presented here is from the variably pumice-enriched top and lithicenriched base of the main body of two flow units $A$ and $\mathrm{B}$ (the third below the top and the topmost of $\mathrm{T} 1$, respectively) sampled within this range. An additional sample is from the middle of a massive, almost unstructured distal flow unit $\mathrm{C}(8 \mathrm{~km}$ from the rim, $9.5 \mathrm{~km}$ from vent), which correlates with or close to $A$ and B. Further data is from the cumulative elutriated dust layer overlying T1 (cf. FREUNDT \& SCHMINCKE, 1986) and from fallout lapilli beds underlying, and intercalated with, T1 (beds VII, IX and X of MLST-A and -B; BOGAARD \& SCHMINCKE, 1984). Table 1 shows the measured data on which the following discussion of abrasion effects is based.

\section{Evidence for abrasion}

This high content of fine ash (smaller 4 phi: 26 to $42 \mathrm{wt} \%$ ), the well-rounded shape of pumice lapilli (measured average form factor $=0.8$ for -2 phi pumice lapilli), and the presence of crystals derived 


\begin{tabular}{|c|c|c|c|c|c|c|}
\hline $\begin{array}{l}\text { Sample } \\
\text { Position }\end{array}$ & $\begin{array}{l}\text { Sample } \\
\text { Number }\end{array}$ & $\begin{array}{l}\text { Distance } \\
\text { from } \\
\text { crater rim } \\
(\mathrm{km})\end{array}$ & $\begin{array}{l}\text { Abrasion } \\
\text { Index }\end{array}$ & $\begin{array}{c}\text { Clean/ } \\
\text { glass- } \\
\text { coated } \\
\text { sanidine }\end{array}$ & $\begin{array}{l}\text { Median } \\
\text { grain } \\
\text { size (phi) }\end{array}$ & $\begin{array}{c}\text { Fraction } \\
\text { smaller } \\
4 \text { phi } \\
(w t \%)\end{array}$ \\
\hline \multicolumn{7}{|l|}{ Flow unit A } \\
\hline Top & 205 & 3,34 & 12,75 & 0.77 & 1,3 & 28,42 \\
\hline Base & 206 & 3,34 & 10,47 & 0.43 & 1,1 & 28,90 \\
\hline Top & 207 & 4,20 & 12,81 & 0,78 & 1,4 & 30,07 \\
\hline Base & 208 & 4,20 & 11.46 & 0,45 & 2,1 & 35,77 \\
\hline Top & 211 & 5.73 & 14,13 & 0,65 & 2.5 & 37.92 \\
\hline Lower third & 212 & 5.73 & 15,49 & 0,38 & 1.5 & 32,38 \\
\hline Base & 213 & 5,73 & 10,53 & 0.84 & 1,2 & 27,94 \\
\hline \multicolumn{7}{|l|}{ Flow unit $B$} \\
\hline T'op & 203 & 3.34 & 12,41 & 0.80 & 1.0 & 25,76 \\
\hline Base & 204 & 3,34 & 12,59 & 0.99 & 1.5 & 30,82 \\
\hline Top & 201 & 3,60 & 8,35 & 0.37 & 1.1 & $, 26,60$ \\
\hline Base & 202 & 3.60 & 14,13 & 0.47 & 1,6 & 28,66 \\
\hline Top & 209 & 5.40 & 9.17 & 0.98 & 2,0 & 33,46 \\
\hline Base & 210 & 5,40 & 14,31 & 0,78 & 1,9 & 31.91 \\
\hline \multicolumn{7}{|l|}{ Flow unit $\mathrm{C}$} \\
\hline Middle & 149 & 7.70 & 11,01 & 0.49 & 2.7 & 41.75 \\
\hline \multicolumn{7}{|l|}{ Dust layer } \\
\hline & 176 & 3,50 & 18.48 & 0.47 & 6,0 & \\
\hline & 163 & 5,40 & 11.73 & 0,32 & 3,3 & \\
\hline \multicolumn{7}{|c|}{ Fallout tephra } \\
\hline MLST-A & VII & 1 & 5.75 & 0.11 & & \\
\hline MLST-A & IX & 1 & 3,98 & 0.36 & & \\
\hline MLST'-B & $X$ & 1 & 6.31 & 0,19 & & \\
\hline ULST & & 20 & 4,5 & & & \\
\hline MLST' & & 20 & 4,5 & & & \\
\hline LEST & & 20 & 5,1 & & & \\
\hline
\end{tabular}

ULST. MLST, and LLST data from Bogaard (1983)

Table 1. Compilation of abrasion-relevant data of $\mathrm{T} 1$ pyroclastic flow units and assocciated fallout tephra.

from destruction of pumice are characteristics of the pyroclastic flow deposits thought to be evidence for strong mechanical abrasion in the depositing flows (WALKER, 1981).

Median (phi) grain size values for flow units $A$ and $\mathrm{B}$ increase steadily from 1 to 1.5 (mean 1.2 ) at the upstream end of the correlated range to 1.2 to 2.5 (mean 1.9) at the downstream end, trending towards the value of 2.7 of distal flow unit C (Fig. 2). Median values for the cumulative dust layer are 6 and 3.3 at different localities representing dust fallout and laterally transported segregation-layer facies, respectively (FREUNDT \& SCHMINCKE, 1986). The fine ash $(<0.06 \mathrm{~mm})$ content in $\mathrm{A}$ and $\mathrm{B}$ parallels the median variation ranging from 25.8 to $30.8 \mathrm{wt} \%$ (mean 28.5) upstream to 27.9 to $37.9 \mathrm{wt} \%$ (mean 32) reaching a peak value $(41.8 \mathrm{wt} \%)$ in the distal flow unit $\mathrm{C}$. These subtle longitudinal grain size variations are, however, small compared to the vertical varia-

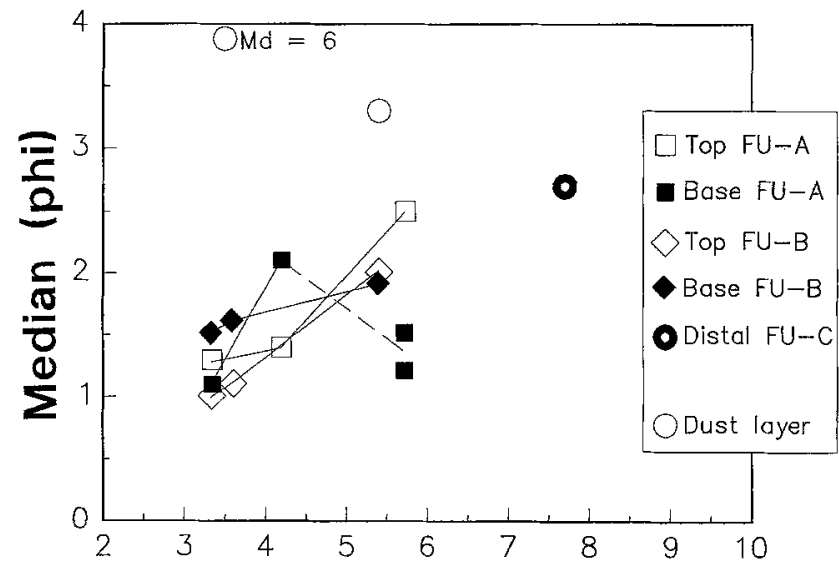

Distance from crater $\operatorname{rim}(\mathrm{km})$

Fig. 2. Variation of median grain size with distance down-valley to the north in the $\mathrm{T} 1$ flow units. The decrease in grain size downstream is mainly attributed to an increase in the fine ash fraction. The two basal samples from FU-A at $5.7 \mathrm{~km}$ are from lithic lapilli-rich zones at the base and $2 / 3$ th above base. Lines connect top and base samples of each flow unit, respectively. 
tions within the flow units at any locality. Furthermore, the slight increase in fines with distance cannot simply be interpreted as an effect of increasing abrasion because it is a function of the balance between competing abrasion and elutriation. Grain size variations, therefore, are no suitable tool to investigate abrasion effects.

Similarly, the crystal content in the matrix ash also does not provide a measure for abrasion. It is controlled by passive enrichment during elutriation of vitric ash as well as abrasion of pumice and lithic particles, whose concentrations again vary vertically and laterally in a pyroclastic flow.

\section{Glass rims on crystals}

The well-rounded pumices proof abrasion of lapilli but what about ash-sized particles? A useful parameter for the documentation of ash-particle abrasion is the size of glass rims adhering to crystals in the matrix ash. Two examples are sketched in figure 3. Glass rims on crystals have been suggested

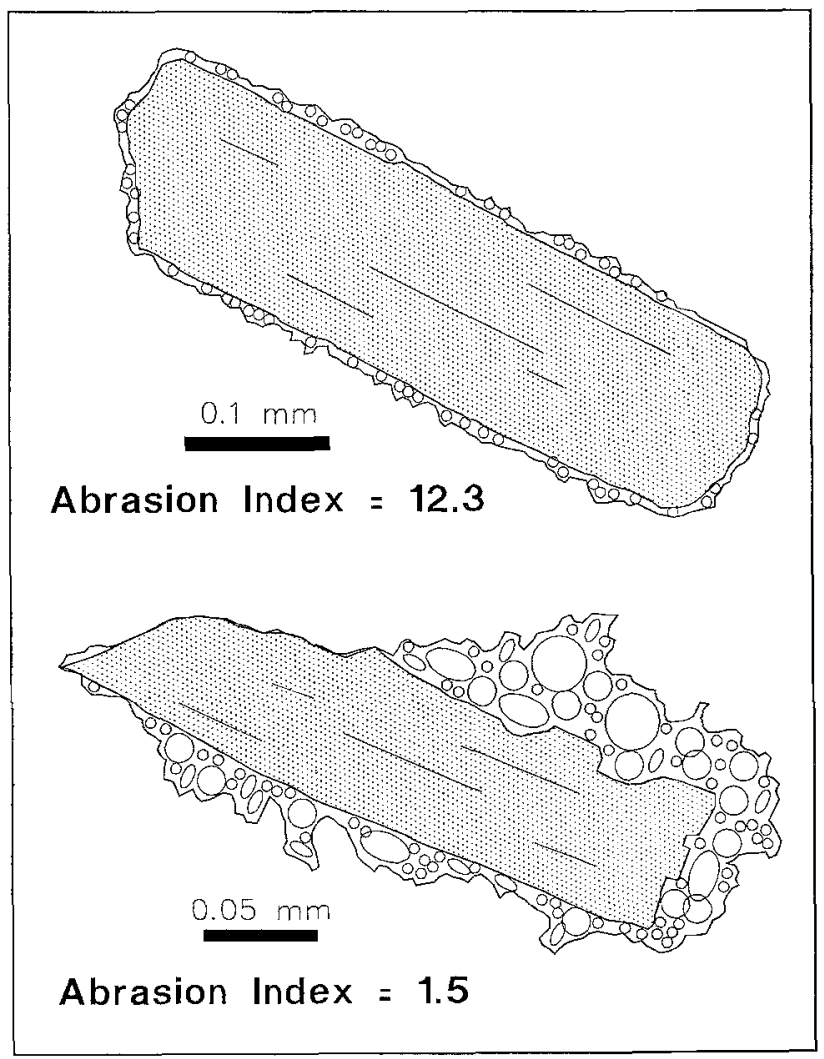

Fig. 3. Sketches of glass-rim bearing heavy minerals with about factor 10 difference in abrasion index. Note how the shape of the large glass rim is controlled by ruptured bubbles while that of the thin glass rim is determined by the shape of the crystal. earlier as indicators of abrasion (FISHER, 1963), and MEYER (1972) defined an

'abrasion index' = area $_{\text {crystal }} /$ area $_{\text {glass rim }}$ and proposed this parameter as a relative measure of the violence of Plinian eruptions. High abrasion indices reflect thin glass rims and vice versa (Fig. 3). We measured crystal and crystal + glass rim areas by image analysis in thin section on 1140 separated heavy minerals in the 3 phi size fraction. We counted only those pyroxenes and amphiboles (plus rare magnetite and sphene) surrounded by clear phonolite glass rims to avoid bias introduced by grains derived from basanitic lithics. We could only measure 50 to 100 grains per thin section, because only about $5 \%$ of the heavy minerals in the flow samples are surrounded by glass rims, in contrast to up to $50 \%$ in fallout samples. This means that in flow samples 95\% of the grains have infinite abrasion indices; values given below refer to the glass-rim bearing subpopulation only. The median value per sample of all measurements of crystals having glass rims is here defined as the abrasion index of a sample.

Abrasion indices of the flow deposit samples (including dust layer) range from 8.4 to 18.5 , with values for individual grains ranging from 0.8 to 390 . Abrasion indices determined on fallout tephra range from 4 to 6.3 (which includes data determined by BOGAARD (1983) for the entire Laacher See fallout tephra) with 0.4 to 70 as the total range for individual grains. Thus very high abrasion indices are found only in the flow deposits. Variance is large in both sample types with sigma values of 1.9 to 3.5. MEYER (1972) found a positive correlation between abrasion indices (5.6 to 19.2) and the erupted fallout tephra volume. The Laacher See fallout data correspond roughly to the low-volume end of his trend (Fig. 4). The crude volume estimates for the individual fallout beds VII $\left(0.32 \mathrm{~km}^{3}\right)$, IX $\left(0.32 \mathrm{~km}^{3}\right)$ and X $\left(0.15 \mathrm{~km}^{3}\right)$ are calculated as fractions (based on their near-vent thickness) of the MLST-A and -B volumes determined by BOGAARD (1983). However, in contrast to MEYER'S observations, the abrasion index of Laacher See fallout tephra remains constant though the fallout dispersal characteristics change significantly within both plinian and phreatomagmatic phases (BOGAARD \& SCHMINCKE, 1984, 1985; SCHMINCKE et al., 1990).

The flow samples have distinctly higher abrasion indices compared to Laacher See fallout and nearly cover the whole range of MEYER's data, though the erupted tephra volume is small (T1 $=0.3 \mathrm{~km}^{3}$; Fig. 4). Figure 5 shows the longitudinal variation of abrasion indices along the northern canyons. There is no systematic variation with distance from the 


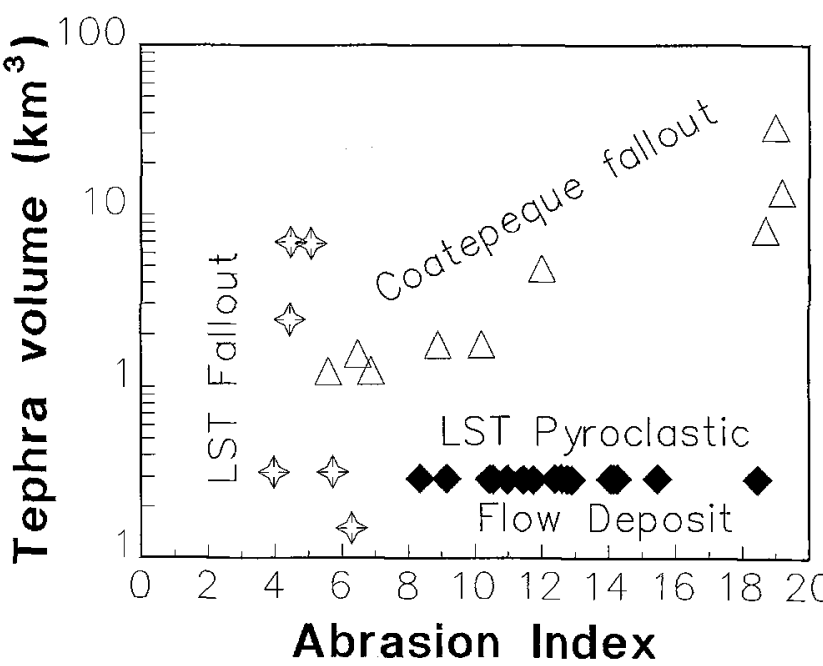

Fig. 4. Erupted tephra volume versus abrasion index for the Coatepeque data (triangles) of MEYER (1972), showing a positive correlation, and for Laacher See Tephra (LST) fallout (stars) and flow deposits (black diamonds). The low-volume LST fallout data refer to MLST-A, B fallout beds stratigraphically closely related to the $\mathrm{Tl}$ pyroclastic flow deposit, but these abrasion indices do not differ from those BOGAARD (1983) determined on samples from throughout the entire LST sequence, here plotting at higher volumes. Note that the LST flow deposits (including dust layer) nearly cover the whole range of abrasion indices observed by MEYER (1972).

vent. Even top to base relationships are opposite in the two flow units A and B investigated. The average value from basal samples is slightly higher than that from top samples but this is not significant in view of the large data scatter. The distal dust layer sample plots right in the flow unit range, and the high value

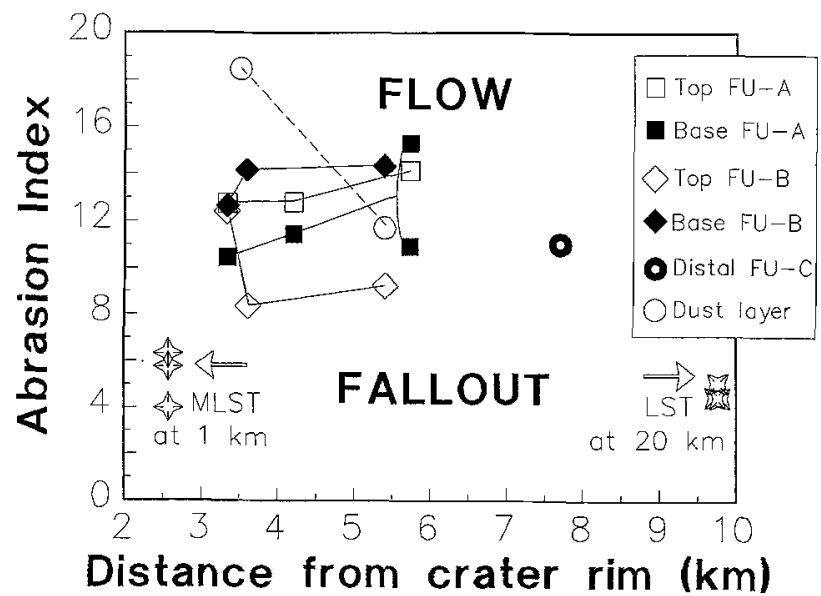

Fig. 5. Abrasion indices of the flow-units do not show any systematic variation with distance but are clearly higher than the values of both near-vent MLST-A, B and intermediately distant LST fallout (from BOGAARD, 1983); note that there is no difference in fallout abrasion indices from these two localities. The vertical variation in abrasion index within a flow unit at a given locality is about the same as the entire variation in the observed range of distance. from the more proximal site is based on the smallest number of measurements since this dust layer sample contained only few heavy minerals.

As a control measurement we have also analyzed the light-mineral fraction, in which sanidine crystals are either clean or are surrounded by thin glass coatings which are too thin for glass-rim measurements and mostly cover only one or two faces of the crystals probably because of their good cleavage. Therefore we just counted both types of grains, and the ratio of clean to glass-bearing sanidine crystals (Fig. 6) shows a variation pattern which is very similar to that of the abrasion indices. Again the flow data are significantly higher than the fallout data, i.e. preserved glass rims are more rare in the flow deposits. Flow unit samples scatter widely with ambiguous top to base relationships and no systematic variation with distance.

Though the relative size and abundance of glass rims on crystals provide quantitative measures for abrasion, the shape of the glass rims does not. The shape of larger glass rims is mainly controlled by the rupture of vesicles whereas once the glass rims are thinner than the average bubble diameter, they still have a ragged surface but the shape is mainly controlled by the shape of the mantled crystal (cf. Fig. 3). Also, there is no significant difference in the shape of glass rims from fallout and pyroclastic flow deposits.

\section{Summary and discussion}

The Laacher See tephra shows significantly smaller and less abundant glass rims on crystals in flow than in fallout deposits. FISHER (1963) did not find such a difference between flow and fallout in the

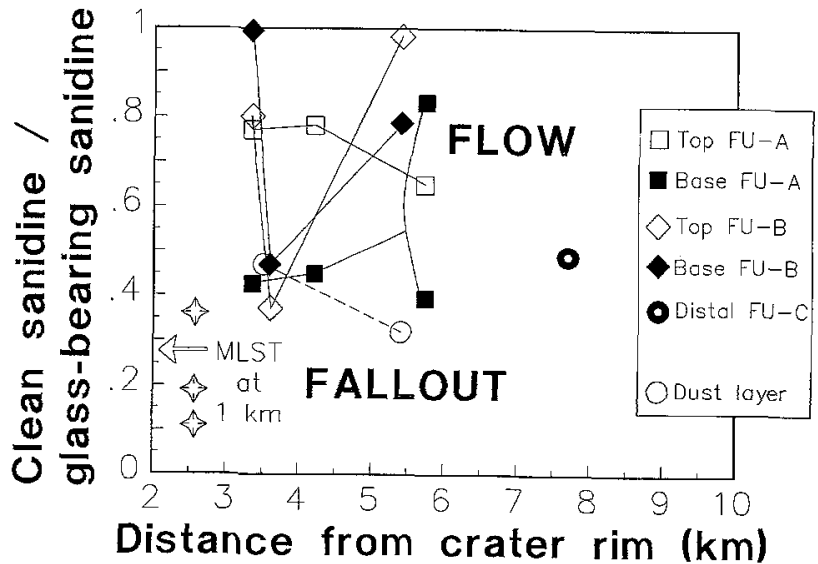

Fig. 6. The number ratio of clean to glass-bearing sanidine crystals varies quite similar to the abrasion indices, showing great non-systematic scatter among flow-unit samples but distinctly higher values for flow than for fallout samples. 
Crater Lake tephra and concluded that abrasion in the pyroclastic flows was not significant, without, however, carrying out a quantitative analysis. The data of MEYER (1972) show that glass rims from higher-volume Plinian fallout are as small as those in the Laacher See pyroclastic flow deposits so that for voluminous eruptions a distinction might no longer be possible. Though larger volume pyroclastic flows might be even more abrasive than the small-volume flows of Laacher See Volcano, measurements become increasingly difficult and inaccurate towards higher abrasion indices. For example, an abrasion index of 400 can represent an only 1 micron thick glass rim continuously covering a $1 \mathrm{~mm}^{2}$ crystal (though, at high abrasion indices, glass rims are no longer continuous).

The significantly higher abrasion indices of glass rims and the well-rounded shape of pumice lapilli in pyroclastic flow deposits compared to fallout tephra at Laacher See are clear evidence for additional abrasion of both large and small grains down to at least c. $0.1 \mathrm{~mm}$ during column collapse and flowage.

Longitudinal variations in abrasion indices clearly need more detailed analyses than presented in this reconnaicance study. However, the lack of obvious systematic variations in the abrasion index in the intermediate to distal region of the flow deposits suggests that the great jump from the abrasion indices generated at the fragmentation site and in the gas thrust in the vent (which are preserved in the fallout tephra) to higher values in the flows was achieved under probably turbulent high-energy conditions during column collapse and near-vent flowage. Hence, while all ash particles pass through an initial phase of abrasion in a dense but highly turbulent suspension in the vent, only the pyroclastic flow ash passes through a second abrasive event which occurs when the dilute material collapsing from the eruption column deflates to form a dense but turbulent suspension during transition into flows (Fig. 7).

Abrasive action seems to have been less effective during laminar flowage through the canyons north of Laacher See (Fig. 7) where the abrasion indices generated under near-vent conditions were modified only to a limited extent. The great scatter within individual flow unit samples, among samples from different flow units, from top or bottom, or from different localities of one flow unit, shows that abrasion in the canyon-confined pyroclastic flows was dominated by local fluctuations in particle interaction. Based on variations in flow unit structures, FREUNDT \& SCHMINCKE (1986) deduced a gradual change from relatively low-viscosity low-strength laminar flowage in the upstream regions to high-

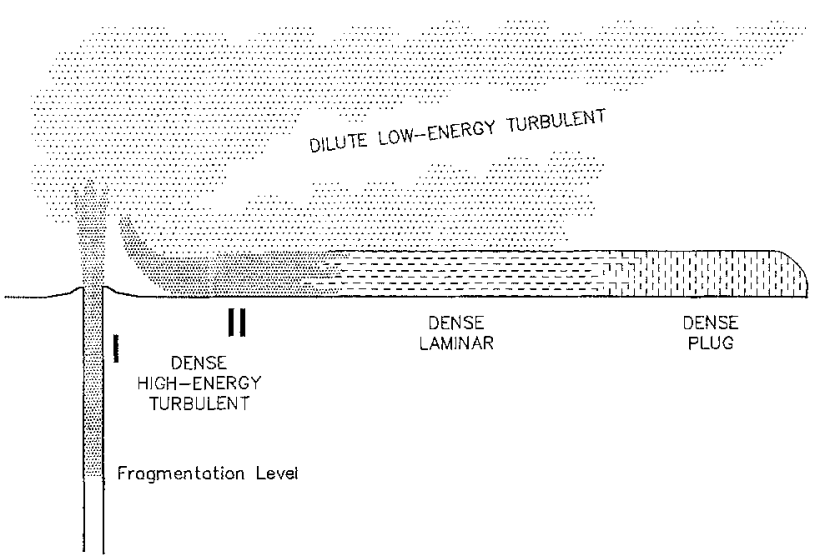

Fig. 7. Cartoon of eruption column and pyroclastic flow depicting two stages of high-energy turbulent motion of a relatively dense ash-gas suspension - the gas thrust and the collapse region - where most efficient grain abrasion is supposed to take place. Abrasion is less efficient during laminar and plug flow, and is minimal in the dilute ash clouds.

viscosity high-strength flow in the downstream sections of the canyons (Fig. 7) but this change apparently did not affect grain abrasion. The increase of fines with distance thus does not reflect an increase in abrasion efficiency but merely a reduced efficiency in elutriation, in agreement with the absence of dust layers in distal sections. There is, therefore, no evidence that diminishing fluidizing gas velocity caused the Laacher See pyroclastic flows to change to strongly abrasive grain flows. On the contrary, abrasion decreased though suspension density increased because of (a) lower-energy impacts and (b) transport of the flows as plugs of ash supported by trapped gas (cf. Mount St. Helens pyroclastic flows; WILSON \& HEAD, 1981) ultimately stopping because of high yield strength and low ground slope.

Transport in dilute turbulent ash clouds apparently has no substantial abrasive effect (Fig. 7) since there is no difference in abrasion indices of fallout tephra from proximal and intermediately distant sites (Fig. 5), and the dust layer samples do not have consistently higher abrasion indices than the pyroclastic flow deposits.

The abrasion behavior of pyroclastic flows deduced here from the glass-rim measurements agrees well with experimental and theoretical studies of particle abrasion in fluidized beds. AYAZI SHAMLOU et al. (1990) showed that high-energy collisions governed by gas motion dominate near the distributor, whereas low-energy collisions governed by contact stresses dominate in the bulk of the bed. Also, the rate of attrition increases as gas velocity increases, and the mode of breakage is predominantly 
by attrition rounding off sharp edges rather than by gross fragmentation. The size distribution of attrition-generated fines was practically independant of their operating conditions.

In conclusion, the relative size of glass rims on crystals in the matrix ash of pyroclastic flow deposits provides a potential tool to investigate abrasive action in the depositing flows and clarify their rheological properties under changing flow regimes.

\section{Acknowledgements}

Discussions with Paul van den Bogaard, a review by Gail Mahood, and financial support by Bundesministerium für Forschung und Technologie (Grant ET 4236 A) are greatfully acknowledged.

\section{References}

Ayazi Shamlou, P., LIU, Z. \& YATES, J. G. (1990): Hydrodynamic influences on particle breakage in fluidized beds. - Chem. Eng. Sci., 45, 809-817.

BogaARD, P.v.d. (1983): Die Eruption des Laacher See Vulkans. - Unpubl. PhD-thesis, Ruhr-Universität Bochum, FRG, $348 \mathrm{pp}$.

- \& SCHMINCKE, H.-U. (1984): The eruptive center of the Late Quaternary Laacher See Tephra. - Geol. Rdsch., 73, 935-982.

— \& - (1985): Laacher See Tephra: A widespread isochronous late Quaternary tephra layer in central and northern Europe. - Geol. Soc. Am. Bull., 96, 1554-1571.

FISHER, R. V. (1963): Bubble-wall texture and its significance. - J. sedim. Pet., 33, 224-227.

FreundT, A. (1982): Stratigraphie des Brohltal-Trass und seine Entstehung aus pyroklastischen Strömen des Laacher See Vulkans. - Unpubl. Diploma-thesis, Ruhr-Universität Bochum, FRG, 319 pp.

- \& SCHMINCKE, H.-U. (1985a): Hierarchy of facies of pyroclastic flow deposits generated by Laacher See-type eruption. - Geology, 13, 278-281.

- \& - (1985b): Lithic-enriched segregation bodies in pyroclastic flow deposits of Laacher See volcano (E-Eifel, Germany). - J. Volcanol. Geotherm. Res., 25, 193-224.
- \& - (1986): Emplacement of small-volume pyroclastic flows at Laacher See (East-Eifel, Germany): Bull. Volcanol., 48, 39-59.

MEYER, J. D. (1972); Glass crust on intratelluric phenocrysts in volcanic ash as a measure of eruptive violence. - Bull. Volcanol., 35, 358-368.

Schmincke, H.-U., BoGaARD, P.v.d. \& Freundt, A. (1990): Quaternary Eifel Volcanism: Excursion 1AI, International Volcanological Congress Mainz, FRG. - Pluto Press, Witten, $188 \mathrm{pp}$.

SchumacheR, R. \& SCHMincKe, H.-U. (1990): The lateral facies of ignimbrites at Laacher See Volcano. - Bull. Volcanol., 52, 271-285.

WALKER, G. P. L. (1981): Generation and dispersal of fine ash and dust by volcanic eruptions. - J. Volcanol. Geotherm. Res., 11, 81-92.

WILSON \& HEAD, J. W. III. (1981): Morphology and rheology of pyroclastic flows and their deposits, and guidelines for future observations. - In: Lipmann P. W. \& Mullineaux, D. R. (eds.) The 1980 eruptions of Mount St. Helens, Washington. U.S. Geol. Survey Prof. Paper, 1250, 513-524. 